1931 Shapland, C.-An analysis of 100 cases of Retinal Detachment treated by Cautery Puncture. Trans. Ophthal. Soc. U.K., Vol. LI, p. 152.

$1931 a$ Gonin, J.- The obliterating thermo-puncture of tears in Retinal Detachment. Ann. d'Ocul. (September), Vol. CLXVIII, p 705.

$1931 b$ Gonin, J.-Results of obliterating cantery puncture, etc. Case XXIX. Ann. d'Ocul. (September), Vol. CLXVIII, p. 719.

1931 Ballantyne, Juler, and Goulden.-A case of Detachment and reflection of the retina. Trans. Ophthal. Soc. U.K., Vol. LI, pp. 113, 115.

1931 Verhoeff, F. H.-Amer. Jl. of Ophthal., Vol. XIV, 1049.

1931 Jeandelize, P., and Baudot, R.-Bull. et Mém. Soc. frang. d'Ophtal., Vol. XLIV, p. 488.

1931 Amsler, M.-Gonin's operation. Klin. Monatsbl. f. Augenheilk., Vol. LXXXVI, p. 1.

1931 Schoenberg, M. J.-Experiences with the Gonin Operation. Arch. of Ophthal., p. 675.

1931 Coppez, L.-Treatment of Retinal Detachment. Le Scalpel, p. 925 (July).

1931 Juler, F. A.-Detachment of the Retina. Trans. Ophthal. Soc.U.K., Vol. LI, p. 164.

1932 Gonin, J.-Ignipuncture or Chemical Cauterisation, etc. Arch. d'Ophtal. (May), Vol. XLIX, p. 292.

1932 Vogt, A.-Klin. Monatsbl. f. Augenheilk., Vol. LXXXVIII, p. 246.

1932 Velhagen, K. - The formation of tears in secondary detachments and the question of detachments amongst young emmetropes. Klin. Monatsbl. f. Augenheilk., Vol. LXXXVIII, p. 317.

Stellwag.-Ophthalmologie, Vol. I, Section 713; Vol. II, Section 552. (Quoted by Scheffels.)

1932 Guist, G.-Chemical Treatment of Detachment. Deutsch. Ophthal. Gesell., Leipsig, May.

1932 Safar.-Treatment of Detachment by Multiple Diathermy. Deutsch. Ophthal. Gesell., Leipzig, May.

1932 Arruga, H.-Seventeenth Assembly of Spanish-American Ophthalmological Society. Congress of French Ophthalmological Society (July).

1932 Larsson, S.-Electro-diathermy in Detachment of the Retina. Vol. VII, p. 661 .

\title{
JOHN ZACHARIAH LAURENCE- A BELATED TRIBUTE
}

BY

\section{ARNOLD SORSBY}

\section{LONDON}

THE passing of John $Z$ achariah Laurence in his 42 nd year in 1870 , was barely noticed by his contemporaries. In the ophthalmic journals of that period there is no mention of his decease, and contemporary English medical periodicals, save for a short and rather patronising paragraph in the Medical Times and Gazette, are likewise silent. Nevertheless his memory has persisted. When Hirschberg came to deal with British Ophthalmology in the second half of the nineteenth century, he found Laurence a noteworthy figure, a learned and inventive man, and one who had aspired to great things; it was a matter for regret that nothing concerning his life was to be obtained from the usual sources of reference. 
Laurence was well and truly interred by his contemporaries. They had come to bury Caesar not to praise him. Eleven years later the Ophthalmic Review appeared under the editorship of Karl Grossmann and Priestley Smith. So well buried was Laurence that the existence of an Ophthalmic Review that he had founded and edited for nearly: four years (1864-7) but which had not survived longer than that, was not mentioned by the editors; presumably the first Ophthalmic Review had been forgotten. And whilst the South London Ophthalmic Hospital founded by Laurence in 1857 grew first into the Surrey Ophthalmic Hospital, then into the Ophthalmic Hospital, Southwark, and into the Royal South London Ophthalmic Hospital, and finally into the present Royal Eye Hospital, the memory of its founder grew ever more faint. His scientific works seemed to have been of ephemeral value-useful contributions to the problems of the day, and of interest only to the historian-when it was shown that the disease described by Bardet in 1920, and Biedl in 1922, and passing into the name of Bardet-Biedl was described in a masterly fashion by Laurence 55 years before in his own Ophthalmic Review.

Of Laurence's early life little is known. The records of University College, London, show that at the age of 19 years, he was entered a student in the Faculty of Arts in the session 1847-48. He takes Latin, Greek, English, Mathematics, Natural Philosophy, Botany and Drawing. Two years later he entered the Faculty of Medicine studying until 1854. Judging by the number of gold and silver medals and prizes he obtained, he appears to have been an exceptionally able student. He became M.R.C.S. in 1854, F.R.C.S. less than a year later, and M.B. London in 1857 .

The early years of his career were devoted to general surgery. At least four minor contributions on Surgery appeared in the year of qualification in the British Medical Journal and the Lancet, and during the subsequent years he appears to have been an active member of the North London Medical Society and the Harveian Society, frequently exhibiting cases and specimens and taking part in the discussions. But his chief contribution in his early years was his book: "The Diagnosis of Surgical Cancer." This was the Liston Prize Essay for 1854, published in 1855. It was well received by the Press. The Lancet (1855, Vol. I, p. 265) praised it rather floridly "Mr. Laurence has got into the right path; many Goliaths no doubt are on the road, but we have great faith in one even young yet zealous for the downfall of of error and establishment of truth." Yet it is hardly more than a compilation such as was to be expected from a newly qualified man. It is a plea for the use of the microscope 


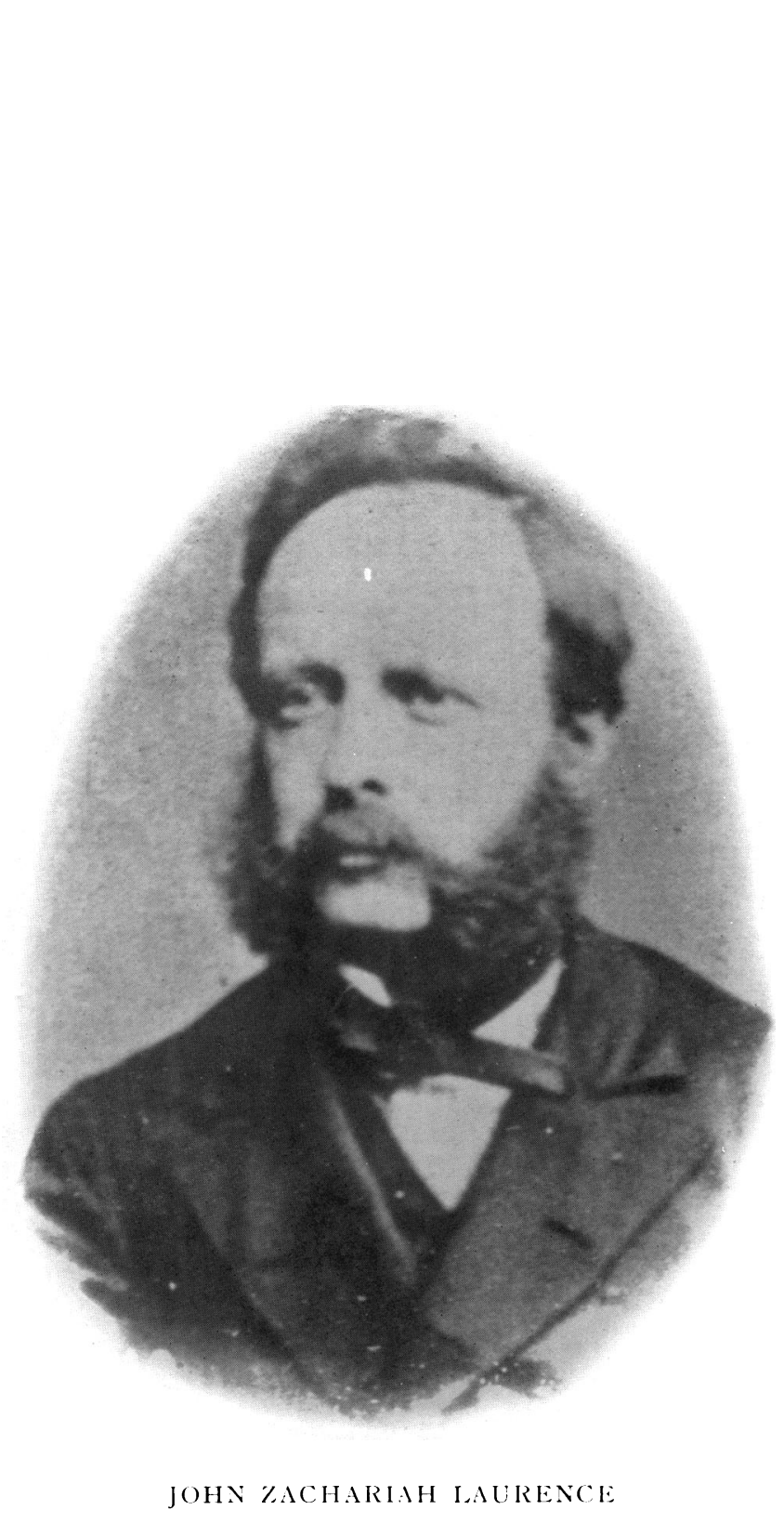

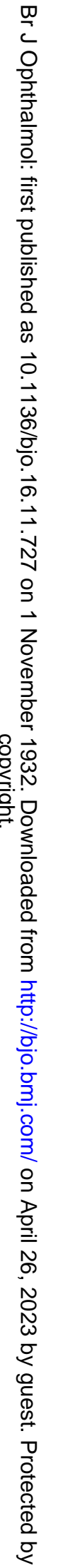


in the diagnosis of malignant disease; in common with his contemporaries in England he attaches excessive importance to a specific cell "the cancer cell," though he admits that "the cancer cell " is not the sine quâ non character of cancer" - " the character of all the cells and of the field of view generally" have to be considered. Much the most significant thing about these unoriginal considerations is the fact that they led Laurence to intensive work on cancer. A series of articles published in 1856- "Illustrations of the Pathology of Cancer"-show the discerning and critical observer. He questions Rokitansky's classification of villous tumours of the bladder and rectum as cancers, pointing out that they do not give rise to secondary deposits, kill by hæmorrhage or intercurrent disease, and can be completely removed surgically. He also advances statistical evidence to disprove the contention that cancer is hereditary. These observations and others equally valuable were incorporated in the second edition of his "Diagnosis of Surgical Cancer" published in 1858. This is no longer the immature effort of an undergraduate, but is packed with careful observations. He reports fifteen cases of melanotic cancer to show the great frequency with which the liver becomes the seat of secondary deposits in this disease; " in only one single case did the liver escape contamination." Well worthy of notice is the chapter on Epithelioma. He holds that it is not a cancer, advancing clinical and pathological evidence for his views. One of the arguments used to show that epitheliomata are cancers was the fact that they recur after excision. Laurence disputes the validity of this argument, pointing out that, excisions performed are too limited to remove the infiltrated area; "indeed one ... would feel more surprised if they did not return . . . when it is considered that in the case of the lips, a certain stereotyped operation, the V-shaped incision, is often so indiscriminately applied." It is only of recent years that this particular teaching has found acceptance. Modern surgical text-books still warn against V-shaped incisions.

One more surgical effort must be noted, a useful contribution to the literature. It was honoured by being read by Richard Quain before the Royal Medical and Chirurgical Society. "On Encephalocele: the history of a case with a tabular analysis of 75 cases" is a painstaking piece of work involving a search through the world literature of two centuries.

All this work together with many minor contributions was completed by 1858 , in the four years following qualification. It fully bore out the opinion expressed in an early testimonial by Professor G. V. Ellis, of Ellis's Anatomy fame- "Besides the ability to acquire information, Mr. Laurence has also an aptitude for 
conducting original investigations so that, if he employs his time diligently, he will be able to add something to our existing knowledge." However it was not as a general surgeon that he was to make his major contributions. What prompted him to abandon surgery in favour of ophthalmology cannot be said. But in 1857 he established the South London Ophthalmic Hospital with the help of Carsten Holthouse, Surgeon to the Westminster Hospital, and from 1860 onwards his attention was devoted exclusively to Ophthalmology.

The South London Ophthalmic Hospital-the present Royal Eye Hospital-started as a modest venture. It grew rapidly but never reached any significant dimension during the 13 years Laurence was destined to be associated with it. In the first six months 298 patients were seen and by the end of ten years 23,178. By 1870, the year of Laurence's death, the new cases for the year had grown to 3,514-about one-seventh of the present annual number. Laurence infused into the hospital his own enthusiasm for knowledge and research.

The fifties and sixties of the last century were stirring years; they brought out the greatness in great men. In the fifties Helmholtz and Graefe laid bare an unknown world by the ophthalmoscope, and in the sixties Donders laid the basis of the modern conception of refraction and accommodation. Laurence came to all this with all the freshness and vigour of youth. The ophthalmoscope was indeed firmly established in England in 1857 and Laurence could but add his quota of ophthalmoscopic observations. Particularly noteworthy is the account of a case of the condition now known as disciform degeneration of the macula; the condition is supposed to have been first noted by von Michel in 1877, but Laurence anticipated him by ten years (First Ophthalmic Review, Vol. III, p. 282).

There are also to his credit two forms of ophthalmoscope, one being a modification of Giraud-Teulon's binocular ophthalmoscope. But in routine work his most important contributions were on refraction and accommodation. When Donders's classic work appeared, Laurence went to Utrecht to study at the fountain head of this new knowledge. On his return he gave a course of lectures on the subject at the hospital, and these lectures apparently found a ready audience. They are mentioned in the annual report of the hospital for 1863 ; they appeared in the Medical Times and Gazette and were published in book form in 1865 (The Optical Defects of the Eye, London, 1865). They are a clear and concise exposition of Donders' teaching and the book found a German translation. The British Medical Journal (1865, Vol. I, p. 616) welcomed it 
freely: "Mr. Laurence is well-known to have carefully studied the pathology of vision according to the light which most recent researches have thrown on it. He is, therefore, thoroughly qualified to give instruction to others and, moreover, shows in this book that he 「can do so]."

Much of his work was of necessity of transient value. Instruments such as his cephalostat for controlling the head of the patient in intra-ocular operations must have been of value in the days before local anaesthesia. It finds a place in Brudenell Carter's "Practical Treatise" of 1875 . His pupillometer is no worse than many other instruments of their kind. His groove-speculum is a forerunner of the modern Lang's speculum. The recognition of astigmatism and the use of cylindrical lenses were still in an early stage and Laurence's cell for determining the axis of cylinders was a useful appliance whilst his simple instrument for measuring squint is still in use as the linear strabismometer.

Of transient value too are most of his articles. "On the shortsight (?) of Squinters," an article published in 1861, in which he shows that in squinters there is a form of short sight which is corrected by convex lenses, and not by concave-this constituting a puzzling type of myopia - is of significance only in so far as it shows the great mercy that was Donders' work. But his practice was always up-to-date. This is evident from press communications and from his book written in collaboration with his house-surgeon. Robert $\mathrm{C}$. Moon (A Handy-Book of Ophthalmic Surgery, London, 1866). He pleaded for iridectomy in glaucoma at a time when there was violent opposition to it; for Mooren's advocacy of preliminary iridectomy in diminishing the danger of cataract extraction and for Javal's stereoscopic exercises in the treatment of squint. He successfully tied the common carotid artery in a case of traumatic aneurysm of the orbit, an operation that was first done by Travers in 1804. Practically his last contribution to ophthalmology was the advocacy of rather bold surgery-excision of the lacrymal gland for epiphora, an advocacy supported by extensive work on the subject.

Laurence is generally credited with being the first to utilise the stereoscope in determining simulated blindness in one.eye, though this is disputed, the credit being ascribed to Jabez Hogg (Norris and Oliver, System of Diseases of the Eye, p. 882, London and Philadelphia, 1900 ; see also Amer. Encvcl. of Ophthal., Vol. XI, p. 1181, Chicago, 1913).

There is no evidence that Laurence was concerned in this test, the error probably arising from the fact that the test is described in Laurence and Moon's Handy-Book of Ophthalmic Surgery. The original description comes from R. C. Moon (First Ophthalmic Review, Vol. II, p. 221). The dispute rests not between Laurence and Hogg but between Moon and Hogg. Laurence's interest in the 
subject is confined to the publication of a short note on the prism test in malingering. (Brit. Med. Jl., p. 965, 1860).

His range of interest was wide ; for besides clinical observations he has to his credit studies in ocular physiology - on accommodation and colour vision and in ocular pathology. But it is not merely as a versatile and able ophthalmologist that he deserves to be remembered. No man sees his work completed, and the work that he started and did not see completed, is to-day a living force. He has become an integral part of modern ophthalmology, as founder of an important hospital, as a pioneer in ophthalmic journalism and as one of the forerunners of that growing school of thought which correlates ocular defect with bodily structure.

His activities as editor, and his description of the condition now known as Laurence-Biedl syndrome deserve fuller consideration.

It is not quite true to say that the Ophthalmic Review was the first English periodical devoted to the speciality. A tentative attempt in this direction was made as early as 1828 by John Richard Farre with the publication of a Journal of Morbid Anatomy, Ophthalmic Medicine and Pharmacological Analysis, with MedicoBotanical Transactions communicated by the Medico-Botanical Society. Only one number appeared, and, as Treacher Collins points out in his History and Traditions of the Moorfields Eye Hospital, the Journal may in a way be considered the precursor of the Royal London Ophthalmic Hospital Reports. It was, however, not till 1857 that these Reports began publication. It was originally intended that they should be published quarterly, and certain limitations on the matter to be published laid down. Laurence, and Thomas Windsor, of Manchester, who collaborated with him, considered there was need for a journal of wider scope. In their introduction to the first issue of the Review they state :-

"... there is no English Journal which displays to the Surgeon a complete account of what is going on at home and abroad in this important branch of Surgery. The Royal London Ophthalmic Hospital Reports (which are no longer issued regularly but only from time to time), most valuable in themselves will on reference be found of a different scope from our Review which is quite as much intended for the profession at large as it is for Ophthalmic Surgeons, and which has taken for its model the well-known "Annales d'Oculistique" and the more recent "Monatsblätter" of Zehender.

The Review fully justified its promise. It was well edited and a valuable feature was the Retrospect of British and Foreign Medical Journals by Thomas Windsor in which contemporary literature was carefully seviewed. From its beginning the Journal showed a great 
partiality for articles from Germany because it held that great advances were being made there. It can hardly be doubted that on the whole it succeeded very well in conveying the great ferment that was going on. But it had its defects; in its reviews of books a personal tone frequently crept in and furthermore, as Hirschberg points out, it counted without the overpowering influence of Moorfields (Grossmacht von Moorfields) and it was not British enough. It relied rather too much on foreign sources for its original contributions. This was an unfortunate combination of circumstances, for it led to an outcry and consequences which were neither dignified nor desirable. The British Medical Journal (Vol. I, p. 424, 1864), found the Ophthalmic Review a surprising production in which British work was being belittled. Jabez Hogg, who was unmercifully flayed in a review of a book of his, was led to the publication of a Journal of British Ophthalmology in which foreign work was discounted and in which abuse was heaped on Laurence and his collaborators. Yet the Ophthalmic Revierw. went on, for the matter was good and the writing frequently little short of brilliant. The review of Hogg's book (Vol. I, pp. 96-109), is especially remarkable ; as polemical writing it is superb. There is no indication as to who wrote it and it is possible that it was not Laurence but Brudenell Carter.

The outcry against the Review for not being sufficiently British was answered by Laurence in a dignified yet impassioned editorial in Vol. II. ("Ophthalmic Surgery at home and abroad.") $\mathrm{He}$ rebuts the charge that English work is being belittled. Reviewing the special circumstances present in different countries which make them best fitted for contributions in special directions he points out that England had not lagged behind, but like other countries is not self-sufficient. The lengthy conclusion of the article deserves full quotation :-

"And if it be asked how England had held her ground, and what, upon the whole, has been her place in this march of progress, the answer is easy and plain. She has done her own work and, in the branches in which she is most fitted to excel, she need acknowledge neither superior nor equal. Her rivalry with the Continent may be altogether friendly, untainted by one single feeling of jealousy or of shame. The names of her great men are household words throughout Europe. The continental journals transcribe, or only slightly condense, nearly everything that is published on ophthalmic matters by their English contemporaries. Her surgeons are eagerly and cordially welcomed at the great continental conferences; and the various improvements with which their names are associated are early tested in every continental hospital. The English surgeons go to the exchange of science to barter, not to borrow; and in such barter they do but recognise the fact that every country contributes 
to the common weal most largely when its energies are mainly directed into the particular channel most favourable to their activity.

When all these things are considered, it is plainly the duty of those who conduct such a journal as this to ignore or forget all distinctions of nationality. The press of England, or Germany, or Holland, or France, or America, furnishes every quarter its store of novelties in facts or in opinions; and this store must be sifted and condensed without a single thought about the various localities that yield it. If the just claims of British surgeons are challenged, these pages will never be backward in advocating and maintaining them. Those who seek for more than this-who would give trivial matter from a countryman the preference over an important contribution from a foreigner, or who complain of the predominance of German material without being able to indicate that any fellow-countryman has been neglected-these seek more than it is possible to give. They may, perhaps, deceive themselves, and may fancy that they believe in their own grievance. In reality they cannot do so. They do but echo the angry and insensate cry-'Are not Abana and Pharpar, rivers of Damascus, better than all the waters of Israel.'

Not in such a spirit as this can the science of healing be rightly studied, or the art be rightly exercised. Nationality forms no barrier against disease, and race gives no exemption from the effects of medicine. There is one sense, at leas in which we are all inmates of the same hospital-all patients of the same Great Physician. It is our privilege to do good to all men, without reference to any of the distinctions that interfere, by reason of race, or language, or station, or religion, with the full display of so many of the other charities of life. In the exercise of this privilege our studies should surely be commensurate with our aims; and our faculties should be as ready to learn as our hands to help. The principle that should guide us was summed up by a great dramatist more than two thousand years ago, in one terse and telling sentence. Of that sentence this article has been but an expansion; and the sentence itself may serve both for a conclusion and a summary :-

'Homo sum ; humani nihil a me alienum puto.'

The Review barely lasted four years; in all, twelve numbers appeared, but an index for the last four issues (Vol. III) was not published. Signs of impending collapse came early in the fourth year when Laurence announced in the eleventh number that Thomas Windsor had withdrawn from the joint Editorship "in consequence of circumstances which possess but a personal interest." Windsor was to continue to write the Retrospect, and these articles indeed appear as before in the last two issues.

Anyone who has turned over the pages of the Review must agree 
with Hirschberg that it deserved a better fate. The first fullfledged British Ophthalmic Journal, with all its faults, was a worthy production.

What led to the collapse of the Review is difficult to say definitely. Feeble outside support and indifference may have killed it, but it is at least as likely that it ceased because the master-hand behind it was withering. It was at this time that Laurence's prolific activities came to a standstill. He was ill during the last two years of his life and probably for longer than that. The journal came to an end late in 1867 ; Laurence's activities during the following year were only fitful. The Minutes of the Royal Eye Hospital for 1869 speak of his illness and absence from the Hospital. If only for the sake of the journal one cannot but regret that this was so.

That chance which favours only those prepared for it, brought under Laurence's observation a small " fat, flat-framed, heavy looking child," who, "instead of looking straight at an object, always looked to one side of it, and on being told to place her hand on anything, she would be unable to direct it at once to the object, but felt about until she came in contact with it. She appeared to see worse as evening approached. In the daylight she was rather slow in her movements; but at night and by artificial light she walked with evident caution, always groping her way about with a degree of uncertainty. She also had a great objection to going out of doors at night, fearing that she would be 'run over'." Ophthalmoscopic examination revealed the appearance of retinitis pigmentosa. In her case there was no evidence of hereditary disposition, nor was she the offspring of a consanguineous marriage, as Liebreich had found to be the case in some of his patients. There was, however, a similar affection in three of her seven brothers, who in addition to the eye lesion, showed peculiar bodily defects; they were all stunted, possessed of a solid, heavy countenance, mentally dull, and in addition showed remarkable under-development of the external genitalia.

"The organs of generation are also strikingly implicated in the general want of development. The penis and scrotum of the eldest boy (Harry) are not larger than those of an infant of 12 months old. Only the left testicle-and that an exceedingly small one-can be felt in the scrotum. A few short brisly hairs are to be seen on the pubes. In the second (Frederick) the penis is somewhat larger, and two small testicles can be distinctly felt in the scrotum. There are a few scattered hairs on the pubes. In the third boy (Charles) no testicles at all can be discovered, his penis and scrotum being about the same size as those of his brother Harry."

The nature of the affection is discussed. 
" In calling these cases by the name of 'Retinitis Pigmentosa,' we have been guided rather by usage than by the intimate nature of the cases. Had we taken the latter view, we should rather have entitled our paper 'Four Cases of Arrest of Development and Atrophy of the Eye'; or we might have gone even a step further in the generalization of our title as the arrest of development was by no means confined to the eye, but affected several other organs of the body. In this latter point of view, and more especially when we regard the general imperfection of the mental faculties, these patients may in a certain sense not be unaptly compared to cretins in a mild degree. In no member of the entire family, however, was there any bronchocele."

This clear picture of familial dystrophia adiposo-genitalis associated with retinitis pigmentosa was completely forgotten and overlooked until Bardet in 1920, and Biedl in 1922 re-described it, and it soon became known as Bardet-Biedl's Syndrome. We owe it to Solis-Cohen and Weiss (Amer. Jl. of Med. Sciences, Vol. CLXIX, p. 489,1925$)$ that Laurence's priority has been established, and in the growing literature on the subject the affection is now generally known as Laurence-Biedl's Syndrome, and sometimes also as the Syndrome of Laurence-Moon-Biedl, Robert Moon having collaborated with his chief in describing the condition. But little has been added to Laurence's description; polydactily has been recorded as an occasional part of the syndrome, and in the light of more extensive knowledge of metabolic disorders, it is now held that it is not the thyroid but the pituitary gland which is at fault in this condition.

If greatness is measured by a man's influence on his contemporaries, there was no greatness in Laurence, in spite of the crowded activity of his short life. But if greatness is measured by the quality of permanence in a man's work, Laurence has claims on more counts than one. Hirschberg considers that Laurence had aspired to do great things but failed to achieve them. With a fuller knowledge of the facts, Hirschberg's verdict would have been different.

Of Laurence's life little is known. From an entry in the Registers of University College he appears to have been born in London. No date could be ascertained. But in 1847 on entering University College he was aged 19 years, and at the time of his marriage in August 1854, he was 25. He must therefore have been born in 1828 or 1829 , too early for his birth to be recorded at 
Somerset House. The record of his marriage preserved at Somerset House, shows that he was married to Miriam Solomon, daughter of Nathaniel Solomon, at the West London Synagogue on August 9, 1854. His father's name is given as Samuel Lewis Laurence. The witnesses were Nathaniel Solomon and Isaac Lewis Lazarus. From his publications it appears that he was Surgeon at the Northern and Farringdon Dispensaries in 1855, and in 1858, Surgeon to the St. Marylebone General Dispensary. After 1858 he does not appear any more as a general surgeon, but as Surgeon to the South London Ophthalmic Hospital. In 1860 he also describes himself as Surgeon [? Ophthalmic Surgeon] to the Hospital for Paralysis, which appointment he does not seem to have held long. Towards the end of his career he was also Ophthalmic Surgeon to St. Bartholomew's Hospital, Rochester (1866-69).

Throughout his career he was intensely interested in the furtherance of Ophthalmology. His name appears among the 81 original members of the German Ophthalmological Society (Heidelberg) in 1864. He also kept in touch with French scientific work, being a member of the Society of Practical Medicine of Paris.

But apart from membership of these Societies and also of the Harveian and Pathological Societies and of the Society of German Naturalists and Physicians, to most of which he contributed papers, he also had wide non-medical interests. He was versatile to a fault; he found relaxation in singing, music, drawing and fishing, and was a fine linguist and a scholarly writer.

He died on July 18th, 1870, after a protracted illness, his active life having come to an end before the beginning of 1869. His wife predeceased him on March 26th, 1863, at the age of 33. One son and three daughters were left, for whom provision was carefully made as revealed in the will dated June 16th, 1868, and preserved at Somerset House (entered September 10th, 1870). One daughter and her children, as also the children of a sister, continue the family at the present time.

Laurence was buried at the side of his wife in the Balls Yond Road Cemetery (Kingsbury Road, N.1), of the West London Synagogue. The inscription on the tombstone speaks of his paternal devotion and his zealous support of medical charities.

It is a pleasant duty to acknowledge the help received in the work entailed in this paper. I am particularly indebted to Miss Millicent M. Oldham, the Alumnus Secretary of University College, London; to Sir George Lewis, Bt., the grandson of the late Sir George Henry Lewis, one of the executors of Laurence's will, and to his cousin Mr. Harry $\mathrm{R}$. Lewis, through whose efforts contact 
with Laurence's descendants was established; to the Secretary of the West London Synagogue, and to the Secretary of the Royal Eye Hospital, Mr. F. E. D'Alton and his staff. I am also obliged to Mr. R. R. James for suggestions and for his sympathetic interest.

\section{SOURCES}

Medical Times and Gazette, London, Vol. II, p. 110, 1870.

Jewish Chronicle, London, July 22, 1870.

BoAse, F., Mod. English Biog., London, Vol. II, 1897.

HIRSCHBERG, J., in Graefe-Saemisch Geschichte der Augenheilk., No. 645 , p. 190 ; No. 666 , pp. $280-284$; No. 710 , p. 459 ; No. 1045 ; Leipzig 1914 and 1918. (The year of death is wrongly given as 1874.)

Plark's Lives of the, Fellows of the Royal College of Surgeons. Bristol, 1930.

(The name is spelt as Lawrence. By a printer's error the place of birth is given as Paris.)

Jewish Encyclopaedia, Vol. VII, 1925.

(Based on Boase and Jewish Chronicle.)

Biographisches Lexicon hervorragender Aertze.

Zweite Auflage, Bd. III, Berlin, 1931.

(Based on Hirschberg.)

LAURENCE's publications.

Minutes of Royal Eye Hospital.

Personal communications and documents; deposited in Archives of Royal Eye Hospital.

\section{PUBLICATIONS BY J. Z. LAURENCE}

BOOKS :

The diagnosis of Surgical Cancer. London, 1855.

Ibid., second edition. London, 1858.

The optical defects of the Eye. London, 1865.

Ibid. German translation by A. Karst. Kreuznach, 1867.

A Handy-book of Ophthalmic Surgery. London, 1866.

\section{ARTICLES :}

(1) British Medical Journal.

Remarkable case of incontinence of urine. P. 1017, 1854.

Illustrations of the pathology of cancer. Pp. 696, 716, 786, 804, 832, 851, $870,886,1856$.

Hip-joint disease: its symptomatology and diagnosis. P. 226, 1859.

A case of sudden death without any adequate post-mortem appearances. P. 376, 1860.

The variations in size of complementary optical spectra. Pp. 619, 695, 1860.

Some observations on the treatment of idiopathic inflammation of the eyes. Vol. I, p. 61, 1862.

On certain functional diseases of the retina. Vol. I, pp. 634, 661, 1865.

Removal of lacrymal gland for lacrymal disease. Vol. II, p. 231, 1866.

(2) Lancet.

Stricture of urethra. Vol. I, p. 653, 1856.

A bearded and hairy female. Vol. II, p. 48, 1857.

On a case of encephalocele. Vol. II, p. 245, 1857.

(This article involved Laurence in an tacrimonious correspondence with Bernard Holt, senior surgeon to the Westminster Hospital. Vol. II, pp. 256, 326, 354, 382, 1857.)

A case of sympathetic ophthaimia cured by neurotomy. Vol. II, p. 633, 1868. 
(3) Medical Times and Gazette.

Illustrations of the treatment of fractures by the starched apparatus. Vol. II, p. 541, 1854.

On certain points in the treatment of stricture. Vol. II. pp. 210, 316, 1855.

Melanotic cancer of the eyeball-operation. Vol. I, p. 461, 1856.

Recent meeting of Naturalists and Physicians at Bonn. Vol. II. pp. 372, 407, 1857.

Encephaloid tumour of bone. Vol. I, p. 449, 1858.

On Rodent ulcer. Vol. II, p. 470, 1858.

Two cases of dislocation of lens. Vol. I, p. 235, 1859.

On the introduction of the catheter. Vol. II, p. 356, 1859.

Anti-phlogistic powers of morphia. Ibid., p. 651 .

The Utrecht school of ophthalmic surgery. Vol. II, pp. 449, 479, 634, 1860 ; Vol. I, p. $85,1861$.

A case of astigmatism completely remedied by cylindrical lenses. Vol. I. p. $210,1863$.

Lectures on the optical defects of the eye. Vol. I, pp. 360, 420, 476, 1864 ; Vol. II, 191, 244, 431, 509, 588, 670, 1864.

An apparatus for fixing the head during operations on the eye. Vol. I, p. $142,1865$.

Groove-speculum. Vol. II, p. 647, 1865.

\section{(4) Medico-Chirurgical Transactions.}

On encephalocele, the history of a case with a tabular analysis of 75 cases. Vol. XXXIX, p. 307, 1856.

(5) Glasgow Medical Journal.

On the short sight (?) of squinters. P. 39, 1861.

The influence of the variations of the size of the pupil on the accommodating power of the eye. P. 268, 1861 .

Some observations on the sensibility of the eye to colour. P. 196, 1862.

(6) Royal London Ophthalmic Hospital Reports.

Hemiopia cotaneous with effusion of lymph on the lower half of the retina. Vol. II, p. 38.

Traumatic paralysis of the circular fibres of the ciliary muscle (and iris). Vol. IV, p. 129

A new oph thalmoscope on the ghost principle. Vol. IV, p. 132.

(7) First Ophthalmic Review.

On some oph thalmic instruments. Vol. I, p. 126.

Diffusion circles. Vol. II, p. 114.

Case reports. Vol. II, p. 378.

Atropine points. Vol. II, p. 426.

Four cases of "Retinitis pigmentosa" occurring in the same family, and accompanied by gross imperfections of development (jointly with R. C. Moon). Vol. II, p. 32.

On removal of the lacrymal gland as a radical cure for lacrymal disease. Vol. III, p. 138.

Cases from Mr. Laurence's practice . . . by R. C. Moon. Vol. III, p. 280.

A case of traumatic aneurysm of the orbit in which the common carotid artery was successfully tied. Vol. III, p. 355.

Further experience on removal of the lacrymal gland as a radical cure for lacrymal disease. Vol. III, p. 361. 


\section{COMMUNICATIONS TO SOCIETIES}

(1) Pathological Society of London.

Reported in Trans. Pathol. Soc:, Vol. VIII, p. 369 ; Vol. XII, p. 201 ; Vol. XVI, p. 235 ; Vol. XVII, p. 271 ; Vol. XVIII, pp. 223, 236.

(2) North London Medical Society.

Reported in Brit. Med. Jl., pp. 336, 626, 1854 ; pp. 20, 131, 461, 467, 1855 ; p. 54, 1856.

Also: The progress of ophthalmic surgery. (1851-63).

An oration to the society on February, 1863. London, Henry Nulchiner, 1863.

(3) Harveian Society.

Reported in Brit. Med. Jl., Vol. I, p. 316, 1862; Vol. I, p. 307, 1863; Vol. II, p. 483, 1863 ; Vol. I, pp. 77, 245, 1864 ; Vol. I, p. 150, 1865 ; Vol. II, p. 667, 1865 ; Vol. II, p. 556, 1868.

(4) German Ophthalmological Society, Heidelberg.

Reported in Klin. Monatsbl.f. Augenheilk., Vol. I, p. 351.

(5) Internat. Ophthal. Congress, Paris, 1867.

Reported Ibid., Vol. V, p. 26.

Contributions to the Series of Illustrations of Hospital Practice in the Brit. Med. JL.

Intense corneitis ; Acute choroiditis, p. 881, 1858.

Diplopia, p. 265 ; Paralysis of sixth nerve: Acute rheumatic ophthalmia, p. 538, 1859.

Acute scleritis and iritis; p. 453, 1860.

Traumatic ophthalmitis, Vol. I, p. 86, 1861.

Brit. Med.Jl.

\section{CORRESPONDENCE}

P. 965,1860 ; Vol. II, pp. 103, 536, 1863 ; Vol. I, p. 596, 1864 ; Vol. II, p. 62,1866 ; Vol. II, p. $403,1868$.

Lancet.

Vol. II, pp. 206, 333, 1855.

Medical Times and Gazette.

Vol. I, p. 99, 1858; Vol. II, p. 458, 1858; Vol. I, p. 657, 1859; Vol. II, p. 219, 1859; Vol. I, p. 576, 1862; Vol. II, pp: $95,155,474,1862$; Vol. I, 632, 1863; Vol. II, 131. 1863; Vol. II, pp. 438, 580, 1864 ; Vol. I, p. 245, 1865. 